\section{Utilization of Hydrocarbons by Micro-organisms}

IT is well known that many micro-organisms can utilize hydrocarbons as a sole carbon source ${ }^{1,2}$. We have as yet little information, however, as to what kinds of intermediate or end products are produced by the microbial dissimilation of hydrocarbons. Above all, the formation of amino-acids from hydrocarbons has not been reported.

We have isolated many strains of micro-organisms from soil samples by elective culture techniques in a medium containing kerosene, mineral salts and 2 per cent of agar, in order to examine if the useful products such as amino-acids, organic acids, fatty acids, steroids, nucleic acids and their derivatives can be produced by those micro-organisms.

Shaking cultures of those micro-organisms were carried out in the medium containing 5 per cent of kerosene and mineral salts (dipotassium hydrogen phosphate, 0.25 per cent; magnesium sulphate, $0 \cdot 1$ per cent; ammonium nitrate, 0.5 per cent; or urea, 0.3 per cent), and we found that 47 strains out of 112 strains of bacteria produced amino-acids and 17 strains produced ultra-violet absorbing substances in their broths, after 4 days' cultivation at $26.5^{\circ} \mathrm{C}$. The kinds of amino-acids detected by paper chromatography were alanine, aspartic acid, glutamic acid, glycine, isoleucine, leucine, serine, tyrosine and valine.

Results of the determination of the amino-acids and morphological studies of those bacteria are shown in Table 1.

Table 1. Some Results of the Derermination of Amiro-Acids

\begin{tabular}{|c|c|c|c|c|c|c|c|}
\hline \multirow[b]{2}{*}{ Strains } & \multirow{2}{*}{$\begin{array}{c}\text { Morpho- } \\
\text { logical } \\
\text { properties }\end{array}$} & \multicolumn{6}{|c|}{ Amino-acids (mg/1.)* } \\
\hline & & Alanine & $\begin{array}{c}\text { Aspar- } \\
\text { tic acid }\end{array}$ & $\begin{array}{l}\text { Glutamic } \\
\text { acid }\end{array}$ & $\begin{array}{l}\text { Iso- } \\
\text { leucine }\end{array}$ & Valine & Lysine \\
\hline$S 7 B 1$ & $\begin{array}{l}\text { Gram nega- } \\
\text { tive rod. }\end{array}$ & & & & & & \\
\hline & Pseudomonas & $17 \cdot 0$ & $23 \cdot 0$ & $23 \cdot 0$ & $15 \cdot 0$ & $38 \cdot 0$ & - \\
\hline$S 10 B 1$ & Unidentified & -. & 0 & $485 \cdot 0$ & - & - & $7 \cdot 5$ \\
\hline$S 10 B 2$ & Unidentified & - & 0 & $200 \cdot 0$ & 一 & - & $5 \cdot 2$ \\
\hline$S 11 B 1$ & Unidentified & 一 & 0 & 98.0 & - & 一 & $1 \cdot \overline{2}$ \\
\hline$S 12 B 2$ & Unidentified & - & $10 \cdot 0$ & $42 \cdot 0$ & $\ldots$ & - & $2 \cdot 4$ \\
\hline$S 17 B 1$ & Unidentified & - & 0 & $54 \cdot 0$ & - & - & $2 \overline{3} \cdot \hat{9}$ \\
\hline$S 31 B 1$ & Unidentified & $50 \cdot 0$ & $11 \cdot 0$ & $74 \cdot 0$ & - & - & $2 \cdot 4$ \\
\hline$S 48 B 3$ & Unidentifled & - & $10 \cdot 5$ & $94 \cdot 5$ & - & - & $1 \overline{7} \cdot 0$ \\
\hline
\end{tabular}

Furthermore, S7B1 strain, which appears in Table I, grew abundantly in the medium containing 5 per cent of kerosene, 0.3 per cent of urea and mineral salts; and the yield of dry cell reached $0.8 \mathrm{~g} / 100 \mathrm{ml}$. after 3 days' cultivation. According to the result of the determination by the Schmidt-Thannhauser method, the content of ribonucleic acid of this dry cell was 5 per cent. It seems possible that economical sources of nucleic acids and its derivatives are supplied by the cell developed in the kerosene-mineral salts media.

KoICHI Yamada

JoJI TAKaHASHI

KaEtsu Kobayashi

Department of Agricultural Chemistry,

Faculty of Agriculture,

University of Tokyo,

Bunkyo-ku.

1 Zobell, C. E., Bact. Revs., 10, 1 (1946).

${ }^{2}$ Beerstecher, jun., E., Petrol. Microbiol. (Elsevier Press, Inc., Houston, New York, 1954).

\section{VETERINARY SCIENCE}

\section{Effect of Air Velocity on the Heat Losses of Sheep and Cattle}

EXPERIMENTS in respiration chambers in which the ambient air temperature could be accurately controlled showed that the air temperature below which heat production increases in response to a fall in air temperature is in calves $13^{\circ} \mathrm{C}$ (ref. 1), in adult cattle $7^{\circ} \mathrm{C}$ (ref. 2) and in sheep with 4-cm fleece $8^{\circ} \mathrm{C}$ (ref. 3). In these experiments air movement was less than 0.5 m.p.h., being that induced by the circulating fans in the chambers. Little informa. tion is available about the effect of air movement on the heat losses of sheep and cattle. Alexander ${ }^{4}$ has shown, however, very large increases in heat production. when lambs are exposed to the blast of a fan and large metabolic effects have been noted in infant caribou exposed to cold windy conditions ${ }^{5}$. Many practical observations show that the production of cattle and sheep, and indeed their very survival, is adversely affected by cold winds.

Two series of experiments have been performed to ascertain the quantitative effect of air movement on the heat losses of these animals. Experiments with steers were made in a respiration chamber ${ }^{b}$ in which air movement was increased from 0.4 to $1.6 \mathrm{~m}$.p.h. by means of small fans and in which the ambient temperature was controlled at either $20^{\circ} \mathrm{C}$ or $0^{\circ} \mathrm{C}$. Each of three steers was exposed to each of the four environments on two occasions, once when with full coat and once when shorn. Each exposure was continuous for 4 or 5 days. Experiments were also made with four sheep which had previously been tracheotomized. These sheep were exposed to cold conditions of $-3,0$ and $+5^{\circ} \mathrm{C}$ in a climatic room ${ }^{7}$ in which air velocities of up to 10 m.p.h. could be obtained by means of a battery of fans. Oxygen consumption was measured by a Douglas bag technique $^{8}$ and heat production computed from the heat equivalent of oxygen determined for each animal in respiration chambers. Measurements were made at different lengths of fleece. With all animals the food given was approximately that required to maintain body-weight in a thermoneutral environment. Skin temperatures were recorded with copper-constantan thermocouples.

With steers, an air movement of $1.6 \mathrm{~m} . \mathrm{p} . \mathrm{h}$. had no effect on heat production at $20^{\circ} \mathrm{C}$ whether the animal was shorn or not, the mean heat production being $8,673 \mathrm{kcal} /$ $24 \mathrm{~h}$. Heat production of steers with coats increased to $8,987 \mathrm{kcal} / 24 \mathrm{~h}$ at $0^{\circ} \mathrm{C}$ in air at $0.4 \mathrm{~m} . \mathrm{p} . \mathrm{h}$. and to 9,490 kcal. at 1.6 m.p.h. Shearing and exposure to $0^{\circ}$ resulted in a heat production of $13,183 \mathrm{kcal} / 24 \mathrm{~h}$ at a wind speed of $0.4 \mathrm{~m} . \mathrm{p} . \mathrm{h}$. and of $13,595 \mathrm{kcal} / 24 \mathrm{~h}$ at a wind speed of $1 \cdot 6$ m.p.h.

The heat production of the sheep in thermoneutral surroundings deviated little from $1,850 \mathrm{kcal} / 24 \mathrm{~h}$. Exposure to a wind of $9.6 \mathrm{~m} . \mathrm{p} . \mathrm{h}$. at an air temperature of $5^{\circ} \mathrm{C}$ increased heat production to $6,469 \mathrm{kcal} / 24 \mathrm{~h}$ in a sheep with $6-\mathrm{mm}$ fleece, to $3,937 \mathrm{kcal} / 24 \mathrm{~h}$ in the same sheep with $20-\mathrm{mm}$ fleece and to $2,317 \mathrm{kcal} / \mathrm{h}$ in another sheep with $50-\mathrm{mm}$ fleece. At air temperatures of $-3^{\circ} \mathrm{C}$ a wind of 4.2 m.p.h. increased heat production to 6,271 $\mathrm{kcal} / 24 \mathrm{~h}$ in a sheep with $10-\mathrm{mm}$ fleece, to $4,699 \mathrm{kcal} / 24 \mathrm{~h}$ in a sheep with $20-\mathrm{mm}$ fleece and to $2,388 \mathrm{kcal} / 24 \mathrm{~h}$ in one with a fleece-length of $50 \mathrm{~mm}$.

External insulation can be defined as the gradient of temperature from the skin surface to the air divided by the sensible heat flow (total heat emission less the heat required to vaporize moisture) per unit surface area per unit time. Table 1 summarizes the results of 65 experiments in which external insulation has been related to the measured length of the coat.

\begin{tabular}{|c|c|c|c|}
\hline Animals & $\begin{array}{l}\text { Wind speed } \\
\text { m.p.h. }\end{array}$ & $\begin{array}{l}\text { No. of } \\
\text { expts. }\end{array}$ & $\begin{array}{l}\text { Regression of external insulation } \\
\left(I_{E}\right) \text { on coat-length }(F)\end{array}$ \\
\hline $\begin{array}{l}\text { Steers } \\
\text { Steers } \\
\text { Sheep } \\
\text { Sheep } \\
\text { Sheep } \\
\text { Sheep } \\
\text { Sheep }\end{array}$ & $\begin{array}{l}0 \cdot 4 \\
1 \cdot 6 \\
0 \cdot 6 \\
2 \cdot 5 \\
4 \cdot 2 \\
7 \cdot 5 \\
9 \cdot 6\end{array}$ & $\begin{array}{r}13 \\
13 \\
10 \\
7 \\
6 \\
9 \\
7\end{array}$ & $\begin{array}{l}I_{E}=5.9+0.37 \mathrm{~F} \\
I_{E}=3.9+0.35 \mathrm{~F} \\
I_{E}=4.8+0.46 \mathrm{~F} \\
I_{E}=4 \cdot 0+0.40 \mathrm{~F} \\
I_{E}=3.2+0.33 \mathrm{~F} \\
I_{E}=2.9+0.35 \mathrm{~F} \\
I_{E}=2.2+0.28 \mathrm{~F}\end{array}$ \\
\hline \multicolumn{4}{|c|}{$I_{E}={ }^{\circ} \mathrm{C} \times 10^{-3} \mathrm{kcal}^{-1} \mathrm{~m}^{2} 24 \mathrm{~h}^{-1} \cdot F=\mathrm{mm}$} \\
\hline
\end{tabular}

Table 1 shows that with both sheep and cattle the gain of insulation due to an increase in coat-length (the coefficient of $F^{\prime}$ ) fell as wind velocity increased. This means that some destruction of the insulation of the hair and wool coats of cattle and sheep occurs in mild winds. The 